\title{
THE ROLE OF HRM IN FOSTERING INNOVATION- A CASE STUDY OF A DUTCH TECHNICAL COMPANY
}

\author{
Peter Nientied \\ NCOI University of Applied Arts, Hilversum, the Netherlands and Polis University, Tirana, Albania \\ nientied1@chello.nl
}

Corella Slob-Winterink

Independent HR interim manager and researcher, Rotterdam, Netherlands

\begin{abstract}
This article discusses the relation between Human Resource Management (HRM) and innovation. Through a case study, in-depth information is collected that may give new insight into how HRM can influence innovation. The case study is a Dutch technical company, a Dutch branch of a German global corporation. It delivers innovative customer solutions in factory automation. The guiding question for the study was "Which HRM practices are important to foster innovation and which HRM practices should receive more attention to achieve the company's innovation ambitions?" A small questionnaire survey structured along the AMO model (abilities, motivation, and opportunities) and complementary interviews were conducted. The results show that the company's HRM has most AMO factors in place, but improvements can be made in cross-departmental teamwork based on team targets instead of individual tasks; these improvements include more facilitated interactions between teams, less focus on quantitative performance standards, and more-flexible organizational procedures and more employee autonomy. The case study indicates that a contingency approach is more appropriate than searching for generalizations of the influence of HRM on innovation and that human resource development/organizational development may be more relevant than working with HRM models such as $A M O$.
\end{abstract}

Keywords: HRM, innovation, AMO model, teamwork, communication, rewarding, performance targets, performance management

\section{INTRODUCTION}

The increasing importance of innovation for organizations, in view of globalization, environmental uncertainties, and rapid technological developments, is widely acknowledged. In a global competitive context, innovations in the workplace can be seen as a springboard for competitive advantage (Bowen et al., 2010). Human Resource Management (HRM) practices are the primary means by which companies can influence and shape the skills and behaviour of individuals to achieve organizational goals (Donate et al., 2017).
Because it is people who are at the heart of creativity and innovation - that is, people develop new ideas and people put them into practice - the relation between innovation and HRM is significant (Bambler et al., 2017). The ensuing question is what HRM could or should do to foster innovation to improve the capabilities and practices of individuals, teams, and the organization. Shipton et al. (2017a) indicated in their introduction to a special issue of the Human Resource Management Journal on this theme that the role of HRM in fostering innovation is important and under-researched. Laursen \& Foss (2014) and Seeck and Diehl (2017) 
Peter Nientied, Corella Slob-Winterink: The Role Of HRM in Fostering Innovation- A Case Study of a Dutch Technical Company

concluded that each of the fields of innovation and HRM has produced impressive amounts of work, but that the relationship between HRM and innovation has developed only slowly. More than a decade earlier, de Leede \& Looise (2005) had already made this point. Apparently, not enough progress has been made to establish firm relations between HRM and innovation. New case studies may give new leads for research on HRM and innovation.

This article studies this relation in a case study of a Dutch technical company working on innovative customer solutions in factory automation. The company, which we anonymize as SK-NL, had 153 employees at the time of the study (2017). SK-NL is a branch of a large German corporation (SK Global). The guiding question for the study was "Which HRM practices foster innovation and which HRM practices should receive more attention to achieve the company's innovation ambitions?" A small questionnaire-based survey was conducted among professionals and managers, observations were conducted, and interviews were held with specialists and managers. The AMO model (abilities, motivation, and opportunities) in relation to innovation was applied. This model was evaluated by Bos-Nehles et al. (2017) and by Seeck and Diehl (2017) and claimed to be relevant for researching the relationship between HRM and innovation. Special attention was given to the selected themes of practices of and experiences with innovation in the company, the system of goal setting, the relation between innovation practices and motivation and the role of management, performance and feedback systems in relation to innovation, and the practice of innovation and bonuses. These items are seen as critical HR practices for fostering innovation. Case studies have inherent limitations of scope. However, case studies are relevant to the current discussion on HRM and innovation. The literature on HRM and innovation is far from conclusive and is under-researched; case studies can provide in-depth insights and lead to new avenues for research. This article briefly reviews and comments upon the recent literature is, and then discusses the case study company and the methodology and results of the study.

\section{LITERATURE REVIEW}

Recently, various articles have taken stock of the academic HRM literature regarding innovation. Bos-Nehles et al. (2017), Seeck and Diehl (2017), Laursen and Foss (2014), Lin \& Sanders (2017), Donate et al. (2016), Andreeva et al. (2017), Prus et al. (2017), Florén et al. (2014), Veenendaal et al. (2014), and Wallo et al. (2016) are notable publications. Together, they provide a good overview of HRM studies with respect to innovation.

Bos-Nehles et al. (2017) conducted a systematic literature review on HRM and innovative work behaviour and used the well-known AMO model as a framework for reviewing the literature. Ability-enhancing HRM practices such as training and development have been proven to be relevant. With regards to motivation-enhancing HRM practices (including rewards), evidence shows that for intrinsically motivated people, rewards have less effect than for more extrinsically motivated workers. Job security as a motivation enhancing practice could not be confirmed in research. Andreeva et al. (2017) pointed out two HR practices that have been widely used to align organizational goals and individual behaviour. Performance appraisal shows positive relations with innovation. Rewards could be bonuses for new ideas or innovative behaviour. However, the effect of such rewards is a contested question. Opportunity-enhancing HRM practices are considered to be contributors to organizational performance. Autonomy has been confirmed as a factor enhancing innovative work behaviour. This seems to be common sense; the opposite - micromanagement by the manager - does not motivate professionals. Seekh \& Diehl (2017) discussed that innovation can be conceptualized as an HRM-related outcome, whereby various HRM practices, alone or in bundles, exert their influence on innovation, possibly through various mediators and depending on different boundary conditions. Positive links between HR bundles (high commitment, collaboration, knowledge development, professionalism, etc.) and HRM practices (training, compensation, appraisal, recruitment, autonomy, etc.) and aspects of innovation have been demonstrated, although the evidence is far from clear (Bos-Nehles et al., 2017). Seekh and Diehl $(2017,927)$ concluded that "Overall, we can 
conclude that HRM influences innovation, but that the research remains fragmented, in particular with regard to measurement and theoretical frameworks, thereby allowing for few generalizations. Given the variety of ways to classify and measure innovation and the various approaches to HRM, the reviewed studies vary widely in their focus and specificity with respect to the independent, dependent, mediating and moderating variables."

The discussion regarding innovation as an HRM-related outcome and the search for generalizations is arduous. First, both concepts of innovation and HRM are broad. Kelly et al. (2013) gave an insightful account of the often-complex nature of innovation and the extensiveness of innovation activities. Sparrow (2016) called for more contingent thinking. Differences in contexts, sectors, cultures, etc. require different approaches. HRM activities for innovation management in, say, the care and cure sectors, are quite distinct from HRM for high-tech firms or retail. Innovation management in the Netherlands, with an open work culture, is very different from, say, South Korea's structured performance culture. Next to sectoral and cultural differences, the type of innovation and the time frame play a role (Conway and Stewart, 2008; Dodgeson et al., 2013; Kelly et al., 2013). Florén et al. (2014) mentioned the following as contingencies: organizational size, type of industry, public versus private sectors, and cross-cultural issues (in national and international firms).

A second point is that much of the recent literature listed at the beginning of this section, tends to consider the relationship between HR and innovation as a black box, compatible with the relation between $\mathrm{HR}$ and performance management (Boselie, 2014; Jiang et al., 2013). "Similarly, parallel to the ongoing discussion of HR and performance, there is a 'black box' between HR and innovation in terms of our understanding of how HRM influences innovation." (Seeck and Diehl, 2017, 926). However, this black box metaphor can be questioned (Jiang et al., 2013). A general instrumental theory in which (bundles of) HRM are identified to enhance innovative behavior and good innovation management cannot do justice to the enormous differences in innovation (management) and HRM contexts. A few decades of research have not resulted in clear HRM instruments and guidelines for enhancing companies' productivity. Although Seeck and Diehl concluded "that HRM influences innovation, but that the research remains fragmented, in particular with regard to measurement and theoretical frameworks, thereby allowing for few generalizations" $(2017,927)$, it can be questioned whether such generalizations can be achieved. A related point is that thinking and research on HRM is still based around large, formal employing organizations (Boxall and Purcell, 2016), with strategic HRM adopting a topdown perspective (Shipton et al., 2017b). But practices in many companies - especially small and medium-sized companies - are rapidly changing, and increasingly are considered as line management and project leaders'/senior professionals' responsibilities. HRM implementation by line managers is determined by the organizational situation in which they operate (Bos-Nehles \& Van Riemsdijk, 2014).

The comments on the current academic discussion on the relationship between HRM and innovation - that concepts are very broad, the need for contingent thinking, the black box metaphor, and top-down thinking - are revisited in the concluding discussion of this article. The next section focuses on the case technical company, SK-NL, in the Netherlands.

\subsection{SK-NL Organization}

The case is the Dutch branch of a large German corporation, SK Group. The global corporation had $€ 2.5$ billion turnover in 2017. The prospects for SK Group and its companies and national branches are positive. The company makes products, systems, and services for pneumatic and electrical control and drive technology for factory automation. The Dutch branch had 153 employees at the time of the survey in 2017. In earlier days the Dutch branch was a sales office of products made in Germany. The mother organization developed from "design, make, and sell" mainly of components to offering solutions for complex factory automation questions through hardware and software. The corporation's national branches help clients with these solutions. Innovation for the Dutch office of SK means finding the right solutions to the complex questions of clients and can be seen as incremental innovation. Digitalization and smart customization (a mix of mass cus- 
Peter Nientied, Corella Slob-Winterink: The Role Of HRM in Fostering Innovation- A Case Study of a Dutch Technical Company

tomization, rapid prototyping, and using big data) in a market in which clients want to have individual solutions will lead to new business models. Innovation is among the main strategic goals of the SK Groups and its branches; globally, $7-8 \%$ of turnover is spent on R\&D. Employees of SK-NL consider the company to be an innovative company because it is focused on the newest techniques and systems and is experimenting with prototypes and fresh solutions. The company's people are aware that the company should continuously innovate in its competitive environment.

SK-NL is not involved in radical innovation or long-term R\&D (that is done in the German headquarters); its focus is on applied technical innovation. With existing kits of components, add-ons, and technical inventiveness, new tailor-made solutions are developed for clients' questions. With various partners, new industrial applications are designed and constructed. In late 2015, the new CEO of the SK Group outlined four priorities for improvement: more collaboration, efficiency, an organizational design with less hierarchy, and improved innovation capability. As a follow-up, various activities were conducted in SK-NL in 2016. However, the discussions and activities did not lead to a SK-NL innovation strategy; the discussion faded.

In addition to incremental innovation of client solutions, SK-NL innovation management related activities include monthly field labs, with an exploration of possible technical solutions; collaboration with higher technical education institutes; networking to share knowledge and expertise; and idea generation among employees. Innovation management is not well-structured in KS-NL. The company acknowledges that innovation management needs improvement but finds it difficult to take the required steps. SK-NL has a traditional organization design in different departments, clusters, and teams. Management and professionals recognize that the organization is rather bureaucratic. Customer Solutions and Supply Chain and Customer Interaction Centre are the largest departments ( 25 and 26 people, respectively); Sales (sales engineering) and Marketing \& Sales Services together have 59 people. In 2017, SK-NL started a first experiment with a flexible work team, a kind of self-organized work team with a scrum method of working. This was good as an ex- periment, but also resulted in some frictions within the organization because the standard bureaucratic way of working was not followed.

SK-NL's HRM priorities include finding and attracting the required highly educated technical staff to enable the company's growth strategy. Strengthening HR practices to foster innovation is a theme generating interest. In this context, the director of SK-NL showed interest in a study of the role that HR could play in fostering innovation.

\section{METHODOLOGY}

This case study used quantitative and qualitative approaches. Desk research and interviews were conducted to make a first inventory of the current situation. From the recent literature, themes on the relationship between HRM and innovation were selected and categories of the AMO model were translated to innovation practices [adapted from Boselie (2014) and Nientied and Shutina (2017)]: practices of and experiences with innovation in the company; goal setting; motivation and the role of management; performance and feedback systems; and rewards/bonuses. These themes were included in a questionnaire survey. Complementary organizational development topics were discussed during interviews, after the survey results were generated.

For the survey, an email was sent to a target group of managers and specialists, and 46 employees showed interest in the study, resulting eventually in 36 valid self-reporting responses without missing values. The group of respondents consisted of managers/team leaders (11) and specialists (25) in technical and sales areas. Management was somewhat overrepresented. Respondents were quite equally distributed among the different departments, with underrepresentation only of the Marketing and Sales Services office. The questionnaire survey was based on the instrument developed by Molleman and Timmermans (2003). This questionnaire (in Dutch) was adapted to cover the AMO themes mentioned above; some questions were added, and others were adjusted to the specific context of SK-NL. The 36 respondents were asked whether they would be willing to be interviewed after the questionnaire survey. Ten respon- 
dents were selected, three in management functions and seven specialists, from various departments. The interviews gave opportunities to substantiate the results of the questionnaire survey and obtain supplementary in-depth information. Interviews were recorded, transcribed, and analysed using labels. Because the survey response was 36 persons, only simple descriptive statistics are used. The survey outcomes are indications only; in the opinion of the researchers, the small number does not allow for meaningful statistical analysis. Statistical reliability in this case study was not the point simple tables with straight numbers are transparent and easy to follow.

The researchers had no conflict of interests. The director did not participate or intervene in the research process. After the research, he was briefed about the results. Anonymity was promised beforehand to respondents and was respected by the director and researchers. Because of the perceived sensitivity of information, the name of the company has been anonymized for this article.

\section{RESULTS}

The results of the study are organized under headings of 1 ) innovation in the company; 2 ) goal setting; 3) motivation and the role of management; 4) performance and feedback systems; and 5) bonuses. After these five points, some issues of the AMO factors and supplementary questions on organizational development are discussed.

\section{Innovation}

Table 1 shows the results of the survey statements regarding opinions of innovation in the company and experiences with innovative workplace behaviour.

The table shows that the company's innovation priorities are understood. Many respondents are involved in working with innovative ideas and customer solutions. The survey results also show that specialists and managers think that their personal innovation potential is underutilized.

During the interviews, the answers to the survey statements were confirmed. Respondents pointed out that innovation efforts were mostly done by the department of Customer Solutions (innovative products and services). Working on new customer solutions gives focus, is down-to-earth, and receives priority because SKNL has a "client first" attitude. Designing new ways to improve innovation management (better systems, better collaboration, better learning and development habits, etc.) helps innovation in an indirect manner, but receives less attention. Interviewees from the Sales team stated that they have limited time to be innovative in their work systems because they are busy with various checklists and the number of visits they must make to (potential) clients. Asked about the possibilities for increasing the innovation capacity of the company, most of the respondents' answers were about better internal collaboration and a culture of joint innovation. Issues such as bonuses, a culture of entrepreneurship, better innovation management, and training were also mentioned, but fewer times. This point is elaborated subsequently.

Table 1: Innovation opinions

\begin{tabular}{|c|c|c|c|c|c|}
\hline Survey statement & $1 \mathrm{SA}$ & $2 \mathrm{~A}$ & $3 \mathbf{N}$ & 4D & $5 \mathrm{SD}$ \\
\hline I1. SK-NL gives adequate attention to innovation at customer level (new customer solutions). & 1 & 18 & 12 & 5 & \\
\hline $\begin{array}{l}\text { 12. SK-NL gives adequate attention to innovation related to internal organizational structures } \\
\text { and processes. }\end{array}$ & & 10 & 15 & 9 & 2 \\
\hline I3. I know SK-NL's innovation priorities. & 6 & 22 & 6 & 2 & \\
\hline 14. I could be more innovative in my function. & 3 & 23 & 5 & 5 & \\
\hline 15. I have enough time for working on new ideas. & 3 & 14 & 6 & 13 & \\
\hline 16. I have many ideas how my team could be more innovative. & 4 & 23 & 6 & 2 & 1 \\
\hline 17. As colleagues, we talk among ourselves about potential innovations. & 2 & 14 & 11 & 8 & 1 \\
\hline
\end{tabular}

$1 S A=$ Strongly agree, $2 \mathrm{~A}=$ Agree, $3 \mathrm{~N}=$ Neutral, $4 \mathrm{D}=$ Disagree, $5 \mathrm{SD}=$ Strongly Disagree. $N=36$. 
Peter Nientied, Corella Slob-Winterink: The Role Of HRM in Fostering Innovation- A Case Study of a Dutch Technical Company

\section{Goal setting}

Working with objectives at work is intended to create focus and performance. Table 2 summarizes the answers about the experiences of respondents.

Table 2 shows that, in general, respondents favour a system of goal setting. The interviews revealed that staff is in favour of goal-setting processes, but that the process should be improved. Various examples were given of positive results achieved in teams, but participation in teams is guided not by teams' work objectives but by the task objectives of the individual members. Respondents said that team goals are not well-defined and discussed with teams, and that more attention to team goals is needed, along with better alignment with individual goals. Individual and team goals in SK-NL are defined in quantitative rather than qualitative terms. Interviewees often said that transparency and communication of team goals should be improved. SKNL has meetings in which teams can show their projects and ask for input, but these meeting often end up in "team selling" and discussions of current operational issues and become less focused on innovative ideas that demand collaboration.

\section{Motivation and the role of management}

Regarding motivation, respondents reacted to a number of statements as follows.

From this table it can be concluded that, in general, the respondents reported a high degree of intrinsic motivation (M1, M3). The engineers of SK$\mathrm{NL}$ are keen on technical challenges and enjoy helping clients with new solutions.

During the interviews, employees working in support jobs (such as customer interaction, which is guided by protocols) reported less intrinsic motivation. The answers to question M4 on compliments and feedback were checked with managers and specialists. Managers were more positive about receiving compliments and positive feedback (mainly from the director) than were specialists (from their managers/team leaders). Managers do not give enough positive feedback, according to their staff. Specialists mentioned during the interviews that ideas receive more positive attention than does the implementation of innovative ideas. They indicated that "many innovative ideas die away" because of the lack of attention to elaborating good ideas into feasible solutions. "Teams need more than creative initiators, they need developers who take pride in turning

Table 2: Goal setting

\begin{tabular}{|c|c|c|c|c|c|}
\hline Survey statement & $1 \mathrm{SA}$ & $2 \mathrm{~A}$ & $3 \mathrm{~N}$ & $4 \mathrm{D}$ & $5 \mathrm{SD}$ \\
\hline G1. Individual goal setting is sensible and stimulates my thinking and acting. & 4 & 23 & 5 & 4 & \\
\hline G2. Team goal setting is meaningful and stimulates team thinking and acting. & 4 & 26 & 2 & 2 & 2 \\
\hline
\end{tabular}

$1 S A=$ Strongly agree, $2 A=$ Agree, $3 N=$ Neutral, $4 D=$ Disagree, $5 S D=$ Strongly. Disagree. $N=36$.

Table 3: Motivation

\begin{tabular}{|c|c|c|c|c|c|}
\hline Survey statement & $1 \mathrm{SA}$ & $2 \mathrm{~A}$ & $3 \mathbf{N}$ & $4 \mathrm{D}$ & $5 \mathrm{SD}$ \\
\hline M1. The nature of my work motivates me to get the best out of myself. & 8 & 19 & 4 & 5 & \\
\hline M2. My manager helps me to get the best out of myself. & 6 & 15 & 6 & 9 & \\
\hline M3. The rewarding systems help me to get the best out of myself. & 1 & 8 & 17 & 9 & \\
\hline M4. I receive enough compliments and positive feedback regarding my innovation work. & 2 & 10 & 14 & 9 & 1 \\
\hline M5. Management team members react in general in a positive manner to innovation ideas. & 1 & 17 & 16 & 2 & \\
\hline M6. My manager coaches me on my innovation capacities. & 2 & 14 & 8 & 12 & \\
\hline
\end{tabular}

$1 S A=$ Strongly agree, $2 \mathrm{~A}=$ Agree, $3 \mathrm{~N}=$ Neutral, $4 \mathrm{D}=$ Disagree, $5 \mathrm{SD}=$ Strongly Disagree. $N=36$. 
ideas into reality and the present practice entails a risk - if we don't achieve innovation results, the interest in presenting new ideas will decrease," said a respondent. Coaching in SK-NL is understood as performance management (checking on progress toward reaching set targets), and not as personal coaching.

\section{Performance management and feedback}

Performance management in SK-NL is organized through performance evaluation discussions(PED), based on a "management by objectives" system.

The respondents' answers to the survey statements on PEDs show that respondents think there is much scope for improving the PED system. Answers to questions P1 and P2 are rather critical. In the current PED system, emphasis is given to quantitative aspects - tangible goals. Innovation work is often not in the quantitative realm.

From the interviews it was learned that innovative capacities are hardly discussed during PEDs; regular em- ployee/supervisor meetings are held monthly and have the character of discussion on work progress. Another objection to the PEDs stated by the respondents is that PEDs are looking backward, and if continuous feedback from the managers would be practiced, the PEDs could be a summary of the past period's feedback plus an overall conclusion and consequences for salary and bonus. In SK-NL, as in many other technical companies, management and staff generally prefer to work with detailed systems. In the case of PEDs, the limitations of such systems become clear. Respondents acknowledged, too, that mutual feedback can be improved; they stated that they want to be able to give better feedback to their colleagues. They can give instant reactions to behaviour or work results of others, but do not have good skills to give constructive feedback.

\section{Rewards and bonus system}

The respondents were asked to react to statements about rewards and bonuses. Table 5 summarizes the answers.

Table 4: Performance and feedback

\begin{tabular}{|c|c|c|c|c|c|}
\hline Survey statement & $1 \mathrm{SA}$ & $2 \mathrm{~A}$ & $3 \mathbf{N}$ & 4 D & $5 \mathrm{SD}$ \\
\hline P1. PEDs help me to improve my innovative capabilities. & 1 & 8 & 11 & 14 & 2 \\
\hline P2. PEDs are good instruments to assess my qualities. & & 16 & 9 & 10 & 1 \\
\hline P3. PEDs are good instruments to assess my performance. & & 18 & 10 & 7 & 1 \\
\hline P4. My manager spends adequate time on feedback and coaching. & 4 & 18 & 9 & 5 & \\
\hline P5. My manager gives enough feedback on the contents of my work. & 5 & 16 & 7 & 6 & 2 \\
\hline P6. I want to be able to give better feedback to my colleagues. & 5 & 10 & 11 & 10 & \\
\hline
\end{tabular}

$1 S A=$ Strongly agree, $2 \mathrm{~A}=$ Agree, $3 \mathrm{~N}=$ Neutral, $4 \mathrm{D}=$ Disagree, $5 \mathrm{SD}=$ Strongly Disagree. $\mathrm{N}=36$.

Table 5: Rewarding and bonuses

\begin{tabular}{|c|c|c|c|c|c|}
\hline Survey statement & $1 \mathrm{SA}$ & $2 \mathrm{~A}$ & $3 \mathbf{N}$ & $4 \mathrm{D}$ & $5 \mathrm{SD}$ \\
\hline R1. My regular salary should be based on my performance. & 11 & 18 & 1 & 6 & \\
\hline R2. My regular salary should be based on my age and experience. & 5 & 11 & 3 & 12 & 5 \\
\hline R3. My bonus should be based on my performance. & 5 & 26 & 2 & 3 & \\
\hline R4. A bonus stimulates my performance more than my salary. & 2 & 5 & 6 & 19 & 4 \\
\hline R5. A bonus stimulates my innovation performance. & 1 & 12 & 7 & 12 & 4 \\
\hline R6. I agree that Sales should earn extra bonuses. & 4 & 13 & 3 & 12 & 4 \\
\hline R7. A team bonus rather than an individual bonus stimulates collaboration. & 6 & 17 & 8 & 3 & 2 \\
\hline
\end{tabular}

$1 S A=$ Strongly agree, $2 \mathrm{~A}=$ Agree, $3 \mathrm{~N}=$ Neutral, $4 \mathrm{D}=$ Disagree, $5 \mathrm{SD}=$ Strongly Disagree. $\mathrm{N}=36$. 
Peter Nientied, Corella Slob-Winterink: The Role Of HRM in Fostering Innovation- A Case Study of a Dutch Technical Company

The answers to the questions about rewards tend to favour a relation between performance and salary, not between performance and bonuses. An interesting point is that the bonus system is not considered to be a crucial factor for innovation; this can be explained by the fact that technical professionals of SK-NL report a high degree of intrinsic motivation. The desk study determined that the wages SK-NL pays are comparable to what is offered elsewhere in specialized technical organizations, and secondary labour conditions are comparable as well. Respondents answered that that performance rather than age and experience should be primary in the rewards system. During the interviews, respondents were asked about the fairness of the rewards and bonus system. Respondents had mixed thoughts - some found it fair enough, whereas others commented that the system is not transparent and that it is unfair that sales people receive a bonus even though a whole team works on a specific solution. In SK-NL the present bonus system is a reward that depends on personal performance and on the company's results. The latter can hardly be influenced by well-performing employees. The general opinion in the company is that the bonus system does not stimulate collaboration. Sales people are in favour of the present bonus system; they benefit most from it.

Looking at specific HR practices of the AMO model (Boselie, 2014) and organizational development topics, the following can be reported from the desk study and interviews.

\section{Selective recruitment and assessment}

The company practices selective recruitment and decides carefully about the selection of new staff. In the last few years, the labour market for technical specialists has become competitive, but SK-NL still attracts enough good applicants. Maintaining good linkages with higher education institutes is one strategy SK-NL uses to find the right talent; offering traineeships is another. SK-NL policy is to search for people who can bring in new talents, because, it was said, "we don't need clones of what we already have." Work engagement and collaboration-mindedness are basic requirements for new hires.
General training and skills training/development for innovation

The company facilitates training, especially in the technical field. Costs of training are of less concern than are days of absence. Training in the field of creativity and innovation is not preferred by management and specialists.

\section{Internal promotion opportunities}

Especially for technical and sales people, SK-NL offers limited promotion opportunities. Based on talents and experience, specialists can participate in specialized teams and they can participate in international projects. Management and technical talents can join an international development program after recommendation of SK-NL, organized by the German headquarters. Opportunities for job rotation are limited, and so are opportunities to work in a managerial role.

\section{Job security}

Job security is offered to all skilled staff after a probation period. In the Dutch context, and especially in the current labour market for technical (sales) specialists, job security is not a critical factor; all companies offer job security, and good engineers can easily find a job. The challenge is for companies to keep their staff. SK-NL participated in good-workplace competitions and ended up among the higher-ranking companies, mainly due to the good employment conditions and the challenging work.

\section{Adequate information and communication}

Employees in SK-NL understand that better communication and feedback is important, but they find it difficult to improve their communication and feedback routines. In an organization that works with a management by objectives system, communication and feedback focus on qualitative goals, and qualitative aspects receive less importance. From the interviews, it was concluded that company culture rather than communication skills is critical. Managers do not foster a culture of giving positive and critical feedback (or feedforward). 


\section{Participation in innovation decision-making}

The culture of SK-NL is rather open when the topic of discussion is of a technical nature. At various levels, specialists can voice their opinions and give inputs. Sales engineers have clients' contacts and can transfer questions and problems of clients and potential solutions for the future. Technical specialists can come forward with innovative ideas. There is no dedicated R\&D department because new materials and new components come from the German HQ. Participation of specialists is limited to giving suggestions, the management makes decisions, and participation in the improvement of management systems is hardly practiced.

\section{Autonomy}

The specialists enjoy autonomy in their work of designing client solutions, but detailed (technical) procedures must be followed. The department of Customer Interaction works with strict protocols and experiences pressure from client-satisfaction ratings, which are visible on monitors in their department, and due to the workload.

\section{Employees are involved in teamwork}

It was noted previously that the functioning of teams is guided by individual task priorities rather than team objectives. This implies that a manager can withdraw a team member when client priorities require response. Working in teams is primarily done to develop solutions for complex clients' questions, and this may require, for example, developing a prototype. This process is delayed when team members are withdrawn. Innovation activities without a direct client demand are important but not urgent and are often rescheduled. The quality of teamwork leaves room for improvement according to the interviewees, and they find more stability in teams in which all members are committed to teamwork; working on the basis of team objectives and a better feedback culture are imperative.

\section{Improving innovation capacity}

Respondents noted that the products of the company - developed by the German $\mathrm{HQ}$ and turned into customer solutions nationally - are high quality, but innovation management is not. When asked about possibilities for improving innovation in SK-KL, several suggestions about organizational issues were shared.

- More flexible organizational design. "We have a culture of consensus and meetings and it takes a lot of time before decisions are made. This hampers innovation and entrepreneurship."

- Better teamwork and collaboration. Teamwork is hampered by the targets of individual employees; teamwork tends to come "on top of it" and teamwork is not guided by team goals and adequate priority setting. This leads to tensions between departments.

- Communication and feedback. It was mentioned that the communication about development and performance (called "coaching" in the company) takes the form of progress discussions. Attention to personal learning and development is not regularly discussed. This is a matter of organizational culture, not a matter of communication skills.

- Management development. Especially specialists suggested that a degree of management innovation is required. Managers and team leaders do not foster a culture of collaboration and innovation and are not role models for better communication and feedback.

\section{DISCUSSION AND CONCLUSION}

The guiding question for this case study was which HRM practices foster innovation and which HRM practices should receive more attention to achieve the company's innovation ambitions. Looking at the AMO factors, it can be concluded that SK-NL has most HR systems related to the AMO model in place. Regarding innovation capabilities, room for improvement can be found in better coaching, better teamwork, and in organizational development. The regular performance evaluation meetings could be made more useful according to specialists, but this relates to management behaviour rather than HR systems. In addition, better feedback and coaching (on the job) will help to improve a culture of innovation. The appraisal system could better accommodate innovation tasks. Teamwork that is driven by project goals and not hampered by task delineation, improved communication between managers and specialists and among special- 
Peter Nientied, Corella Slob-Winterink: The Role Of HRM in Fostering Innovation- A Case Study of a Dutch Technical Company

ists, and a more flexible form or organizational design (a more flexible bureaucracy) are critical area for improvement. Rousseau et al. (2013) concluded on the basis of their empirical work that team leaders who engage in coaching behaviours toward their subordinates are likely to foster innovation within their work teams, and therefore organizations may benefit by designing and implementing interventions aimed at developing team leaders' coaching skills and encouraging them to consider coaching as a core managerial responsibility. Similar conclusions were made by Sanders et al. (2016); in their study of HRM and innovation in four German and Dutch technical companies, they concluded that manager-employee exchange and satisfaction with work content and with influence had the strongest influence in explaining innovative behaviour. In our study, firm statistical evidence cannot be given, but it seems that the main factors are indeed work content and the relation with the manager (especially feedback and performance evaluation), and cross-sectional teamwork and the slow bureaucratic organizational model. A practical point may be mentioned: Bos-Nehles and van Riemsdijk (2014) found in their survey that line management claimed that they have insufficient time for HR tasks. This point was also raised by managers and team leaders of SK-NL. However, one may argue that this is not a matter of time, but a matter of priorities - a mindset of devoting adequate attention to people. In SK-NL, managers and team leaders are overly involved in administrative and business processes, and (as is often the case with technical specialists who become managers) are still involved in technical work because they find it too interesting and fail to delegate such work to their people.

In the review of theory, comments were submitted on the current academic discussion about the relationship between HRM and innovation; these comments included opinions that the HRM and innovation concepts are very broad and there is a need for contingent thinking, that the black box metaphor may not be the right metaphor, and that logical top-down thinking of HRM research can be questioned.

\section{Broad concepts and contingency approach}

Regarding the broad concepts, the case study suggests that interventions to improve incremental innovation are rather practical. In the case of SK-NL, promoting creativity to explore technical solutions and finding partners in an open innovation system is not an issue, but better teamwork and more organizational flexibility are. In the German headquarters of SK, different issues are likely to demand priority because research in a large company to develop new materials, for example, demands different competences, procedures, and organizational context in R\&D structures. A broad focus on HRM in terms of the logic of AMO factors to promote innovation leads to superficial findings. Florén et al.'s (2014) contingencies of organizational size, type of industry, and cross-cultural issues of national or international firms all seem relevant. Also important is the nature of innovation at stake, because the concept of innovation is wide-ranging. The SK-NL case study in view of the academic discussion of the relationships between HRM and innovation suggests that an organizational development (OD) perspective is more relevant than is a conventional HRM-AMO perspective.

\section{The black box metaphor and top-down thinking}

The logic of strategic HRM is, in short, determining which HRM's AMO factors should be modified to influence innovation performance. For the case of SK$\mathrm{NL}$, it was shown that this is not the most productive approach. It appears that organizational development rather than HRM's AMO factors are relevant for improving incremental innovation activities. This approach also assumes that companies have effective innovation strategies, which is usually not the case (Tidd and Bessant, 2013; Dodgeson et al., 2014; Pisano, 2015). In contemporary organizations, such as SK-NL, the distinction between management practices and HRM [in the form of human resource development (HRD)] can hardly be made in organizational practice. Aagaard and Andersen (2014) suggested that traditional HR themes such as recruitment, training, and development have to be reinterpreted in a context of heterogeneity and polyvalence, and further suggest that HR should focus on broader issues such as team-based organizing founded on a questioning attitude and a management style with a high level of empowerment. They suggested seven (still under-researched) HR practices for supporting innovation: 1) promoting an innovation culture; 2) training and development with an investment approach; 
3) team organizing with a high input of diversity; 4) talent management; 5) performance management; 6) management style based on empowerment; and 7) recruitment and selection to attract new knowledge. These HR practices are in the field of organizational development/HRD. Further exploration of
OD/HRD looks promising, as Sheehan et al. (2014) suggested. Withers (2012) argued for a strategic role of OD and suggested that an OD strategy can be shaped from an HR perspective. Such an approach seems to fit the issues emerging from our case study and should have a wider relevance.

\section{EXTENDED SUMMARY / IZVLEČEK}

Članek obravnava odnose med ravnanjem s človeškimi viri (HRM) in inovacijami. Študija primera je omogočila zbiranje poglobljenih informacij o vplivih HRM-ja na inovacije. Študija primera se osredotoča na nizozemsko tehnološko podjetje, podružnico ene izmed nemških globalnih korporacij. Prispevek ponuja inovativne rešitve na področju ravnanja s strankami ter tovarniške avtomatizacije. Glavno vprašanje, ki ga prispevek obravnava je: "Kateri načini ravnanja s človeškimi viri so pomembni za spodbujanje inovacij in katere prakse HRM bi morale več pozornosti nameniti doseganju inovacijskih ambicij podjetja?" Študija primera je bila izvedena s pomočjo kratkega anketnega vprašalnika, strukturiranega vzdolž modela AMO (sposobnosti, motivacija in priložnosti), skupaj z dopolnilnimi intervjuji. Rezultati kažejo, da v kontekstu študije HRM vključuje večino dejavnikov modela AMO. Kljub temu so možne izboljšave, predvsem na področju medsektorskega timskega dela. Slednji naj bi tako vključeval več timskega dela na podlagi skupinskih ciljev namesto posameznih nalog; te izboljšave omogočajo močnejše sodelovanje med ekipami, manj osredotočenja na kvantitativne kazalnike uspešnosti, bolj prilagodljive organizacijske postopke in večjo avtonomijo zaposlenih. Študija primera dokazuje, da je situacijski pristop bolj primeren kot iskanje splošnih vplivov HRM-ja na inovacije in da je razvoj človeških virov lahko bolj pomemben kot delo s HRM modeli, kot je AMO.

\section{REFERENCES}

Aagaard, A., \& Andersen, T. (2014). How can HR practices support front-end innovation and increase the innovativeness of companies? European Journal of International Management, 8(5), 488-505.

Andreeva, T., Vanhala, M., Sergeeva, A., Ritala, A., \& Kianto, A. (2017). When the fit between HR practices backfires, Exploring the interaction effects between rewards for and appraisal of knowledge behaviours on innovation. Human Resource Management Journal, 27(2), 209-227.

Bamber, G.J., Bartram, T., \& Stanton, P. (2017). HRM and workplace innovations, Formulating research questions. Personnel Review, 46(7), 1216-1227.

Boselie, P. (2014). Strategic human resource management, a balanced approach. Maidenhead Berkshire, McGraw Hill.

Bos-Nehles, A., Renkema, M., \& Janssen, M. (2017). HRM and innovative work behaviour: a systematic literature review. Personnel Review, 46(7), 1228-1253.
Bos-Nehles, A., \& Van Riemsdijk, M. (2014). Innovating HRM Implementation, the influence of organisational contingencies on the HRM Role of line managers. In Advanced Series in Management 14: Human Resource Management, Social Innovation and Technology, p. 101-133.

Bowen, F.E., Rostami, M., \& Steel, P. (2010). Timing is everything, a meta-analysis of the relationships between organizational performance and innovation. Journal of Business Research, 63(11), 1179-1185.

Boxall, P., \& Purcell, J. (2016). Strategy and Human Resource Management. London: Palgrave Macmillan, 4th ed.

Conway, S., \& Steward, F. (2009). Managing and shaping innovation. Oxford: Oxford University Press.

Diaz-Fernandez, M., Bornay-Barrachina, M., \& LopezCabrales, A. (2017) HRM practices and innovation performance: a panel-data approach. International Journal of Manpower, 38(3), 354-372.

Dodgson, M., Gann, D.M., \& Phillips, N. (eds.) (2014). The Oxford handbook of innovation management. Oxford: Oxford University Press. 
Peter Nientied, Corella Slob-Winterink: The Role Of HRM in Fostering Innovation- A Case Study of a Dutch Technical Company

Donate, M.J., Peña, I., \& Sánchez de Pablo, J.D. (2016). HRM practices for human and social capital development, Effects on innovation capabilities. The International Journal of Human Resource Management, 27(9), 928-953.

Florén, H., Rundquist, J., Schuler, R.S., Bondarouk, T., \& Ruël, H. (2014). HRM and innovation: themes, contingencies and directions for future research. European Journal of International Management 8(5), 570-577.

Francis, H., Holbeche, L., \& Reddington, M., eds. (2012). People and organisational development, a new agenda for organisational effectiveness. London: CIPD - Kogan Page.

Goller, I., \& Bessant, J. (2017). Creativity for innovation management. Abingdon: Routledge.

Jiang, K., Takeuchi, R., \& Lepak, D.P. (2013). Where do we go from here? New perspectives on the black box in strategic human resource management research. Journal of Management Studies 50(8), 1448-1479.

Keeley, L., Pikkel, R., Quinn, B., \& Walters, H. (2013). Ten types of innovation, the discipline of building breakthroughs. Hoboken NJ: Wiley.

Laursen, K., \& Foss, N. J. (2014). Human resource management practices and innovation. In M. Dodgson, D. Gann, \& N. Phillips (eds.) Handbook of innovation management. Oxford, Oxford University Press. p. 505-530.

Leede, J. de, \& Looise, J.K. (2005). Innovation and HRM: Towards an integrated framework. Creativity and Innovation Management, 14(2), 108-117.

Lin, C., \& Sanders, K. (2017). HRM and innovation: a multilevel organisational learning perspective. Human Resource Management Journal, 27(2), 300-317.

Molleman, E., \& Timmerman, H. (2003). Performance management in een innovatieve omgeving. Bedrijfskunde, 75, 78 - 87.

Nientied, P., and Shutina, D. (2017). High performance work practices in Albania. Journal of Human Resource Management, 20(2), 12-20.

Pisano, G.P. (2015). You need an innovation strategy. Harvard Business Review 93(6), 44-54.

Prus, I., Nacamulli, R.D.C., \& Lazazzara, A. (2017). Disentangling workplace innovation: a systematic literature review. Personnel Review, 46(7), 1254-1279.

Rousseau, V., Aubé, C., \& Tremblay, S. (2013). Team coaching and innovation in work teams, an examination of the motivational and behavioral intervening mechanisms. Leadership \& Organization Development Journal, 34(4), 344-364.

Sanders, K., Moorkamp, M., Torka, N., Groeneveld, S., \& Groeneveld, C. (2010). How to support innovative behaviour? The role of leader member exchange (LMX) and satisfaction with HR Practices. Technology and Investment 1(1), 59-68.
Seeck, H., \& Diehl, M-J. (2017). A literature review on HRM and innovation - taking stock and future directions. The International Journal of Human Resource Management, 28(6), 913-944.

Sheehan, M., Garavan, T.N., \& Carbery, R. (2014). Guest editorial, Innovation and human resource development (HRD). European Journal of Training and Development, 38(1/2), 2-14.

Shipton, H., Budhwar, P., Sparrow, P., \& Brown, A. (2017a). Editorial overview: HRM and innovation - a multilevel perspective. Human Resource Management Journal, 27(2), 203-208.

Shipton, H., Budhwar, P., Sparrow, P., \& Brown, A. (2017b). HRM and innovation: looking across levels. Human Resource Management Journal, 27(2), 246-263.

Sparrow, P. (2016). Strategic HRM, innovation and HR delivery for human resource management, innovation and performance. In Shipton, H., Budhwar, P., Sparrow, P. and Brown, A. (eds.) Human Resource Management, Innovation and Performance, Basingstoke: Palgrave Macmillan, p. 15-31.

Tidd, J., \& Bessant, J. (2013). Managing innovation, integrating technological, market and organizational change. Chichester: Wiley.

Veenendaal, A.A.R., van Velzen, M., \& Looise, J.K. (2014). Affecting innovation through HRM: the role of creative capital. European Journal of International Management 8(5), 472-487.

Wallo, A., Kock, H., \& Nilsson, P. (2016). Setting the stage for innovation: towards a conceptual model of the HR-innovation link. International Journal of Human Resources Development and Management, 16(1/2), $100-120$.

Withers, M. (2012). Developing an organisational strategy from an HR perspective. In: Francis, H., Holbeche, L., \& Reddington, M. (eds.). People and organisational development, a new agenda for organisational effectiveness. London: CIPD - Kogan Page, p. 68-88.

Acknowledgement: The authors want to thank two anonymous reviewers of DRMJ for their useful comments on an earlier version of the article. 